\section{Research Square}

Preprints are preliminary reports that have not undergone peer review.

They should not be considered conclusive, used to inform clinical practice, or referenced by the media as validated information.

\title{
Efficacy and safety of antiplatelet agents in patients with COVID- 19 a systematic review and meta-analysis of observational studies
}

Yan $\mathrm{Hu}$

Dalian Medical University

Baohui Song ( $\nabla$ songbh2690@163.com )

Dalian Medical University https://orcid.org/0000-0002-8182-9253

Systematic Review

Keywords: COVID-19, Antiplatelet agents, Mortality, Meta-analysis

Posted Date: June 17th, 2021

DOI: https://doi.org/10.21203/rs.3.rs-417531/v1

License: (9) This work is licensed under a Creative Commons Attribution 4.0 International License. Read Full License 


\section{Abstract}

Coagulopathy and thrombotic events have been reported in patients with coronavirus disease 2019 (COVID-19) frequently. However, the use of antiplatelet agents in COVID-19 is yet to be investigated. This article systematically reviewed the relationship between use of antiplatelet agents and major outcomes of COVID-19 patients. In total, 12 studies met our eligibility criteria. Due to high heterogeneity, we excluded three studies with high risk of bias. The result showed that antiplatelet therapy did not related to a higher mortality of COVID-19 patients ( $\mathrm{OR}=1.01,95 \% \mathrm{Cl}=0.77-1.33, \mathrm{I}=0 \%, \mathrm{P}=0.88)$. However, the use of antiplatelet agents was associated with a lower risk of $\mathrm{ICU}$ admission $(\mathrm{OR}=0.63,95 \% \mathrm{Cl}=0.40-0.98, \mathrm{I} 2=0 \%, \mathrm{P}=0.68)$ and mechanical ventilation $(\mathrm{OR}=0.57,95 \% \mathrm{Cl}=0.38$ $0.85, I 2=0 \%, P=0.75$ ) compared with those without antiplatelets. In conclusion, current results did not support that antiplatelets will cause greater mortality in patients with COVID-19 infection. Antiplatelet agents should be continued in COVID-19 patients, unless clinically indicated.

\section{Introduction}

An outbreak of coronavirus disease 2019 (COVID-19) is responded to severe acute respiratory syndrome coronavirus-2 (SARS-CoV2) occurred[1]. It has been declared as a global pandemic on 11 March 2020. Until 30 March 2020, more than 12 million have been infected, and over 2.8 million deaths in COVID-19[2]. A prominent signature of COVID-19 is high risk of thrombosis, which complicates SARS-CoV-2 infection[3].

SARS-CoV-2 leads to diffuse endothelial inflammation and dysfunction via angiotensin converting enzyme (ACE-2) receptors, which will disturb the hemostatic balance[4]. Simultaneously, platelet adhesion and aggregation initiated, thromboinflammatory process developed gradually. Activation of platelet has been considered to be crucial for promoting the pathogenesis by maintaining the severe inflammatory in respiratory system, which exacerbated acute lung injury and death at the late postinfarction time points $[5$, $6]$.

Since there is no validate treatment, many existing drugs have been tried for the treatment of COVID-19. Aspirin is a typical antiplatelet agent with strong anti-inflammatory and anti-thrombotic effects, which is related to the reduced mortality and lower risk of acute respiratory distress syndrome in severe patients without COVID-19[7, 8]. However, current use of aspirin for patients with COVID-19 is still controversial.

Our understanding of the efficacy and safety of antiplatelet agents in COVID-19 still in early stages. Until now, few randomized clinical trial data regarding to antiplatelet agents for patients with COVID-19 could be obtained. Hence, summarizing the efficacy and safety of antiplatelet agents in COVID-19 patients timely may help more physicians to administer antiplatelet agents properly. In this review, we summarized the association between antiplatelet drugs and adverse outcomes of patients with COVID-19, and analyzed the benefits and risks.

\section{Method}

\subsection{Literature search}

This review was conducted in accordance with the guidelines of preferred reporting items stated in the system review and metaanalysis (PRISMA) to ensure high quality of evidence. PubMed, MEDLINE, Google Scholar, Scopus, the Web of Science, and the Cochrane Central Register of Controlled Trials (CENTRAL), and Chinese databases (CNKI, WANFANG and Sino Med) were searched from beginning to 31 March 2021 to update our preliminary results. The search was restricted for English and Chinese articles, which were published after 31 st of December, 2019. The full search strategy is included in (Figure 1).

\subsection{Inclusion and Exclusion Criteria}

The searched articles were imported into EndNote reference management software. Two independent investigators screened the title/abstracts firstly to identify potentially eligible studies, then any duplicate is removed. Observational studies about antiplatelet agents on adults ( $\geq 18$ years) patients with COVID-19, except for narrative reviews or opinion-based publications, were included, and other relevant information. When the information was incomplete in the articles, we attempted to contact the corresponding authors to get it. 
Data was extracted and coded in the electronic spreadsheet by two reviewers. Baseline characteristics: title, study year, first author, study country, sample size, etc. Patient characteristics: age, gender, intervention measures and the name of antiplatelet agents, etc. Outcome: number of deaths, number of patients with mechanical ventilation, intensive care unit (ICU) admission.

\subsection{Statistical analysis}

In this study, the statistical analyses were performed with Cochrane RevMan 5.3. The Newcastle-Ottawa Scale (NOS) was applied for assessing the quality of cohort and case control was used to evaluate the included studies[9]. The scores were recorded in the electronic spreadsheet by two reviewers. They were blinded to each other's decisions. If there was any disagreement, it was resolved by discussion or consultation with the third review.

For dichotomous variables, Mantel-Haenszel formula was applied for the calculation of odds ratios (OR) and $95 \%$ confidence intervals $(95 \% \mathrm{Cl})$. The level of heterogeneity among the studies was assessed by $\mathrm{I}^{2}$ statistic. If $\mathrm{I}^{2} \leq 50 \%$, suggesting that the results were homogeneous, and the fixed effect model was used. If $\mathrm{I}^{2}>50 \%$, accompanied by $\mathrm{P}<0.05$, indicating that the results were heterogeneous, so the random effects model was performed in the present analysis. If significant heterogeneity was found, the analysis of subgroups will be conducted. Funnel plots were used to assess publication bias.

\section{Results}

\subsection{Patient characteristics}

The characteristics of patients included in this study are shown in Table 1.

All of the selected studies were published in 2020 and 2021 with different sample patient sizes that ranged from 31 to 26346 patients. The average age of the subjects was ranged from 52 to 79 . Eleven included studies compared mortality outcomes of COVID-19 patients using antiplatelet agents with non-users. Two studies compared mechanical ventilation outcomes, while 2 compared ICU admission outcomes, respectively. Nine studies included 30582 patients with COVID-19 totally, 7184/30582(23.5\%) of who were treated with aspirin alone. Three studies were conducted in China, 3 in the USA, 2 in the UK, and 1 each from Italy, Iran, and Israel. The results of the quality assessment of the selected studies are presented in Supplementary Table S1 and S2.

\subsection{Meta-analysis}

\subsubsection{Use of antiplatelet agents and mortality of COVID-19 patients}

The mortality analysis included eleven studies. In the studies included, 7260 COVID-19 patients treated with antiplatelet agents and 23673 without antiplatelet agents. The risk associated with antiplatelet therapy and death was verified. Overall, the risk of mortality in patients with antiplatelet agents was similar to those without antiplatelet agents ( $O R=0.67,95 \% \mathrm{Cl}: 0.41-1.09, \mathrm{I}^{2}=89 \%, P<0.001$ )

(Figure 2A). However, there was high heterogeneity among the included studies. In the following sensitivity analysis, we excluded three studies with high risk of bias. Without obvious heterogeneity, the pooled adjusted result indicated no significant association between antiplatelet agents and mortality $\left(\mathrm{OR}=1.01,95 \% \mathrm{Cl}=0.77-1.33, \mathrm{l}^{2}=0 \%, \mathrm{P}=0.88\right)$ (Figure 2B).

\subsubsection{Use of antiplatelet agents and risk of mechanical ventilation, ICU admission in COVID-19 patients}

Two studies provided the data in terms of antiplatelet agents and the risk of ICU admission in COVID-19 patients. Fixed-effect model was used for further assessment, for low heterogeneity in these studies. The result suggested that patients with antiplatelet agents at a lower risk of $\mathrm{ICU}$ admission (OR=0.63, 95\% Cl= 0.40-0.98, $\mathrm{I}^{2}=0 \%, \mathrm{P}=0.68$ ) (Figure $3 \mathrm{~A}$ ). Two studies were evaluated for antiplatelet agents and the risk of mechanical ventilation. We observed that patients who have received antiplatelet agents got a lower risk of mechanical ventilation $\left(\mathrm{OR}=0.57,95 \% \mathrm{Cl}=0.38-0.85, \mathrm{I}^{2}=0 \%, \mathrm{P}=0.75\right)$ (Figure 3B).

\subsubsection{Subgroup analysis}


To further explore the correlation between antiplatelet agents and mortality, subgroup analysis was conducted. The detailed results are presented in Figure 4. In the subgroup analysis, we observed that the age of patients was associated with the risk of mortality (OR=1.46, 95\% Cl: $\left.1.08-1.97, \mathrm{I}^{2}=37 \%, \mathrm{P}=0.12\right)$. In addition, other subgroup analysis results showed no statistical significance (all $\mathrm{p}>0.05)$.

\subsubsection{Publication bias}

The test for publication bias was conducted by funnel plot (Figure 5). Good symmetry was shown and studies were distributed on both sides of the pooled outcome clearly. It indicated that there was no significant publication bias in current studies.

\section{Discussion}

This review included 12 articles, more than 30,000 COVID-19 cases encompassed. Our findings suggest that antiplatelet therapy did not increase the risk of death in COVID-19 patients. However, patients who received antiplatelet agents were associated with a lower risk of ICU admission and mechanical ventilation. This review has provided a rationale for the rational use of antiplatelet agents during the COVID-19 pandemic.

Up to date, no consensus guidelines are available for antiplatelet therapy in COVID-19, while conflicting results of mortality were reported by the various clinical studies. Liu, et al. (2020), Liu, et al. (2021), Meizlish, et al. (2021), Merzon, et al. (2021), Osborne, et al. (2021) reported that antiplatelet therapy was associated with lower risk of mortality compared with non-antiplatelet agents users[10-14]. It has been reported that SARS-CoV-2 participant in the activation of platelets directly and promote thrombosis, which might be an important cause for the high incidence of thrombotic events in COVID-19 patients[6] [4, 15]. According to this theory, COVID-19 patients may profit from antiplatelet therapy. However, Sahai, et al. (2020), Alamdari, et al. (2020), Chow, et al. (2021), Russo, et al. (2020), Yuan, et al. (2020) have shown that there was no difference on mortality between patients with and without antiplatelet agents[16-20]. Giacomeill, et al. (2020) found that non-survivors were more frequently being treated with anti-platelet agents[21]. Conclusions presented above show that antiplatelet agents have no significant benefit on mortality. For most COVID-19 patients present of comorbidities and risk factor of the death, a full consideration should be taken for advantages and disadvantages of antiplatelet therapy.

Patients with COVID-19 has a high incidence of thromboembolic events[22]. Among non-COVID-19 patients, antiplatelet agents are strongly related to a lower incidence of thrombotic events[23]. But our results showed that treatment with antiplatelet agents was not associated with mortality in COVID-19 patients. The results reported by Husam, et al. suggested no protective effect of aspirin in patients with COVID-19[24]. Patients receiving antiplatelet agents tend to have risk factors of death from COVID-19, including diabetes, coronary heart disease, etc. Therefore, it is possible that we have underestimated the protective effects of antiplatelet agents on COVID-19 mortality.

This review also has several limitations. First, it included a broad range of COVID-19 patients, lack of uniform diagnostic criteria of SARS-CoV-2 infection. Second, deficiency of clinical data precluded us in evaluating some variables such as duration of antiplatelet agents use, dosage, etc. Third, the studies from different countries lead to heterogeneity in definition of antiplatelet therapy and experiment design. Fourth, except for aspirin, outcomes of other kinds of antiplatelets in the COVID-19 patients are also of interest. Finally, more studies are needed to confirm long-term outcomes in COVID-19 patients who received antiplatelet agents.

In conclusion, our results suggested that the use of antiplatelet agents did not lead to an increasing mortality in COVID-19 patients. Additionally, the available evidence indicates that antiplatelet therapy results in lower risk of ICU admission and mechanical ventilation. Antiplatelet agents should be continued in COVID-19 patients, unless clinically indicated.

\section{Declarations}

\section{Authors' contributions}

B.H.S. conceived the study and revised the manuscript critically for important intellectual content. Y.H. made substantial contributions to its design, acquisition, analysis and interpretation of data. All authors read and approved the final manuscript. 
Declaration of Competing Interest

The authors declare that they have no competing interest.

Funding

This research did not receive any specific grant from funding agencies in the public, commercial, or not-for-profit sectors.

\section{References}

1. Hu B, Guo H, Zhou P, et al. Characteristics of SARS-CoV-2 and COVID-19. Nat Rev Microbio/ 2021; 19,(3):141-154.

2. Johns Hopkins University COVID-19 Dashboard by the Center for Systems Science and Engineering (CSSE) at Johns Hopkins University. [https://coronavirus.jhu.edu/map.html]

3. Wichmann D, Sperhake J-P, Lütgehetmann M, et al. Autopsy Findings and Venous Thromboembolism in Patients With COVID-19: A Prospective Cohort Study. Ann Intern Med 2020; 173,(4):268-277.

4. Varga Z, Flammer AJ, Steiger P, et al. Endothelial cell infection and endotheliitis in COVID-19. Lancet 2020; 395, (10234):1417-1418.

5. Levi M, Thachil J, Iba T, et al. Coagulation abnormalities and thrombosis in patients with COVID-19. Lancet Haematol 2020; 7,(6):e438-e440.

6. Godino C, Scotti A, Maugeri N, et al. Antithrombotic therapy in patients with COVID-19? -Rationale and Evidence. Int J Cardiol 2021; 324,(261-266.

7. Du F, Jiang P, He S, et al. Antiplatelet Therapy for Critically III Patients: A Pairwise and Bayesian Network Meta-Analysis. Shock 2018; 49,(6):616-624.

8. Hamid U, Krasnodembskaya A, Fitzgerald M, et al. Aspirin reduces lipopolysaccharide-induced pulmonary inflammation in human models of ARDS. Thorax 2017; 72,(11):971-980.

9. Cochrane Handbook for Systematic Reviews of Interventions Version 5.1.0. The Cochrane Collaboration. [www.cochranehandbook.org]

10. Liu Q, Huang N, Li A, et al. Effect of low-dose aspirin on mortality and viral duration of the hospitalized adults with COVID19. Medicine $2021 ; 100,(6): \mathrm{e} 24544$.

11. Liu X, Li Z, Liu S, et al. Potential therapeutic effects of dipyridamole in the severely ill patients with COVID-19. Acta Pharm $\operatorname{Sin} B 2020 ; 10,(7): 1205-1215$.

12. Meizlish ML, Goshua G, Liu Y, et al. Intermediate-dose anticoagulation, aspirin, and in-hospital mortality in COVID-19: A propensity score-matched analysis. American journal of hematology $2021 ; 96,(4): 471-479$.

13. Merzon E, Green I, Vinker S, et al. The use of aspirin for primary prevention of cardiovascular disease is associated with a lower likelihood of COVID-19 infection. The FEBS journal 2021.

14. Osborne TF, Veigulis ZP, Arreola DM, et al. Association of mortality and aspirin prescription for COVID-19 patients at the Veterans Health Administration. PloS one 2021; 16,(2):e0246825.

15. Zost SJ, Gilchuk P, Case JB, et al. Potently neutralizing and protective human antibodies against SARS-CoV-2. Nature 2020; 584,(7821):443-449.

16. Sahai A, Bhandari R, Koupenova M, et al. SARS-CoV-2 Receptors are Expressed on Human Platelets and the Effect of Aspirin on Clinical Outcomes in COVID-19 Patients. Research square 2020. 
17. Alamdari NM, Afaghi S, Rahimi FS, et al. Mortality Risk Factors among Hospitalized COVID-19 Patients in a Major Referral Center in Iran. Tohoku J Exp Med 2020; 252,(1):73-84.

18. Chow JH, Khanna AK, Kethireddy S, et al. Aspirin Use Is Associated With Decreased Mechanical Ventilation, Intensive Care Unit Admission, and In-Hospital Mortality in Hospitalized Patients With Coronavirus Disease 2019. Anesthesia and analgesia 2021; 132,(4):930-941.

19. Russo V, Di Maio M, Attena E, et al. Clinical impact of pre-admission antithrombotic therapy in hospitalized patients with COVID-19: A multicenter observational study. Pharmacological research 2020; 159,(104965.

20. Yuan S, Chen P, Li H, et al. Mortality and pre-hospitalization use of low-dose aspirin in COVID-19 patients with coronary artery disease. Journal of cellular and molecular medicine 2021; 25,(2):1263-1273.

21. Giacomelli A, Ridolfo AL, Milazzo L, et al. 30-day mortality in patients hospitalized with COVID-19 during the first wave of the Italian epidemic: A prospective cohort study. Pharmacological research 2020; 158,(104931.

22. Wright FL, Vogler TO, Moore EE, et al. Fibrinolysis Shutdown Correlation with Thromboembolic Events in Severe COVID-19 Infection. J Am Coll Surg 2020; 231,(2).

23. He P, Yang C, Ye G, et al. Risks of colorectal neoplasms and cardiovascular thromboembolic events after the combined use of selective COX-2 inhibitors and aspirin with 5-year follow-up: a meta-analysis. Colorectal Dis 2019; 21,(4):417-426.

24. Salah HM, Mehta JL. Meta-Analysis of the Effect of Aspirin on Mortality in COVID-19. Am J Cardio/ 2021; 142,(158-159.

\section{Tables}

Table 1. Characteristics of the Included Studies. 


\begin{tabular}{|c|c|c|c|c|c|c|c|c|c|c|c|}
\hline \multirow[t]{2}{*}{ Author } & \multirow[t]{2}{*}{ Year } & \multirow[t]{2}{*}{ Country } & \multirow{2}{*}{$\begin{array}{c}\text { Study } \\
\text { design }\end{array}$} & \multirow{2}{*}{$\begin{array}{l}\text { Study } \\
\text { period }\end{array}$} & \multirow{2}{*}{$\begin{array}{c}\text { Treat with } \\
\text { antiplatelet } \\
\text { agents }\end{array}$} & \multirow{2}{*}{$\begin{array}{c}\text { No } \\
\text { antiplatelet } \\
\text { agents }\end{array}$} & \multirow{2}{*}{$\begin{array}{c}\text { Average } \\
\text { age }\end{array}$} & \multicolumn{2}{|c|}{ Sex } & \multirow{2}{*}{$\begin{array}{l}\text { Antiplatelet } \\
\text { agents used }\end{array}$} & \multirow[t]{2}{*}{ Outcomes } \\
\hline & & & & & & & & Male & Female & & \\
\hline Alamdari, et al. & 2020 & Iran & $\begin{array}{c}\text { Single } \\
\text { center } \\
\text { study }\end{array}$ & $\begin{array}{c}\text { January } \\
2020 \text { to } \\
\text { April } \\
2020\end{array}$ & 53 & 406 & 62 & 320 & 139 & Aspirin & Mortality \\
\hline Chow, et al. & 2021 & USA & $\begin{array}{l}\text { Multicenter } \\
\text { study }\end{array}$ & $\begin{array}{l}\text { March } \\
2020 \text { to } \\
\text { July } \\
2020\end{array}$ & 98 & 314 & 55 & 244 & 168 & Aspirin & $\begin{array}{c}\text { Mechanical } \\
\text { ventilation, } \\
\text { ICU } \\
\text { admission, } \\
\text { mortality }\end{array}$ \\
\hline $\begin{array}{c}\text { Giacomelli, et } \\
\text { al. }\end{array}$ & 2020 & Italy & $\begin{array}{c}\text { Single } \\
\text { center } \\
\text { study }\end{array}$ & $\begin{array}{c}\text { February } \\
2020 \text { to } \\
\text { March } \\
2020\end{array}$ & 33 & 200 & 61 & 161 & 72 & - & Mortality \\
\hline Liu, et al. & 2020 & China & $\begin{array}{l}\text { Multicenter } \\
\text { study }\end{array}$ & $\begin{array}{c}\text { February } \\
2020 \text { to } \\
\text { March } \\
2020\end{array}$ & 14 & 17 & 56 & 21 & 10 & Dipyridamole & Mortality \\
\hline Liu, et al. & 2021 & China & $\begin{array}{l}\text { Single } \\
\text { center } \\
\text { study }\end{array}$ & $\begin{array}{c}\text { January } \\
2020 \text { to } \\
\text { March } \\
2020\end{array}$ & 28 & 204 & 52 & 32 & 16 & Aspirin & Mortality \\
\hline Meizlish, et al. & 2021 & UK & $\begin{array}{l}\text { Multicenter } \\
\text { study }\end{array}$ & $\begin{array}{l}\text { March } \\
2020 \text { to } \\
\text { June } \\
2020\end{array}$ & 319 & 1821 & - & 1396 & 1389 & Aspirin & Mortality \\
\hline Merzon, et al. & 2021 & Israel & $\begin{array}{l}\text { Multicenter } \\
\text { study }\end{array}$ & $\begin{array}{c}\text { February } \\
2020 \text { to } \\
\text { June } \\
2020\end{array}$ & 7 & 105 & 59 & 61 & 51 & Aspirin & Mortality \\
\hline Osborne, et al. & 2021 & USA & $\begin{array}{l}\text { Multicenter } \\
\text { study }\end{array}$ & $\begin{array}{l}\text { March } \\
2020 \text { to } \\
\text { August } \\
2020\end{array}$ & 6324 & 20022 & 58 & 23487 & 2859 & Aspirin & Mortality \\
\hline Russo, et al. & 2020 & Italy & $\begin{array}{l}\text { Multicenter } \\
\text { study }\end{array}$ & $\begin{array}{c}\text { February } \\
2020 \text { to } \\
\text { April } \\
2020\end{array}$ & 55 & 147 & 68 & 115 & 77 & Aspirin & Mortality \\
\hline Sahai,et al. & 2020 & USA & $\begin{array}{l}\text { Multicenter } \\
\text { study }\end{array}$ & $\begin{array}{c}\text { March } \\
2020 \text { to } \\
\text { May } \\
2020\end{array}$ & 248 & 248 & - & - & - & Aspirin & Mortality \\
\hline $\begin{array}{c}\text { Sivaloganathan, } \\
\text { et al. }\end{array}$ & 2020 & UK & $\begin{array}{c}\text { Single } \\
\text { center } \\
\text { study }\end{array}$ & $\begin{array}{l}\text { March } \\
2020 \text { to } \\
\text { April } \\
2020\end{array}$ & 29 & 58 & 79 & & & $\begin{array}{c}\text { Aspirin, } \\
\text { clopidogrel }\end{array}$ & $\begin{array}{l}\text { Mortality, } \\
\text { ICU }\end{array}$ \\
\hline Yuan, et al. & 2020 & China & $\begin{array}{c}\text { Single } \\
\text { center } \\
\text { study }\end{array}$ & $\begin{array}{c}\text { January } \\
2020 \text { to } \\
\text { March } \\
2020\end{array}$ & 52 & 131 & 71 & 99 & 84 & Aspirin & Mortality \\
\hline
\end{tabular}

\section{Figures}


Records from preliminary search of PubMed, MEDLINE. Google Scholar, Scopus, the Web of Science, and the Cochrane Central Register of Controlled Trials (CENTRAL), and Chinese databases (CNKI, WANFANG and Sino Med) $(n=514)$

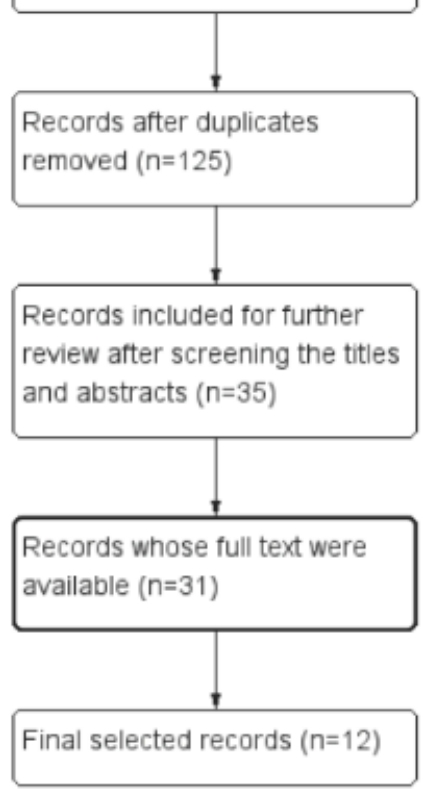

\section{Figure 1}

Flow diagram of study selection and identification. 
A

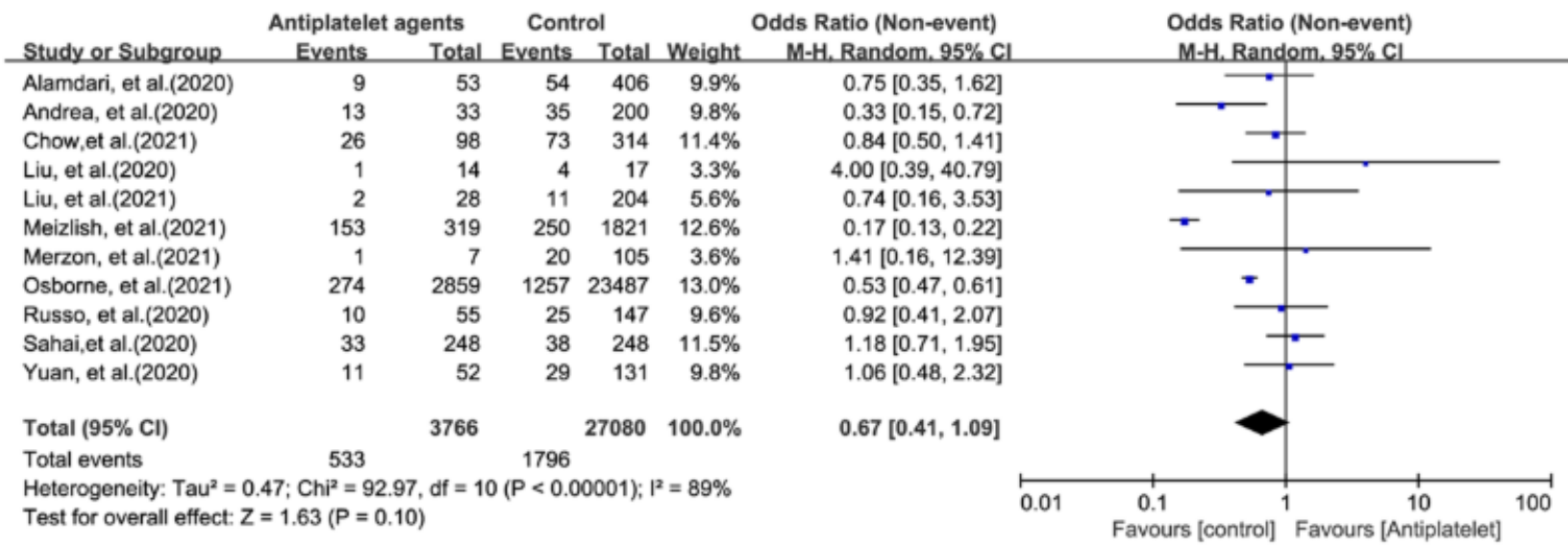

B

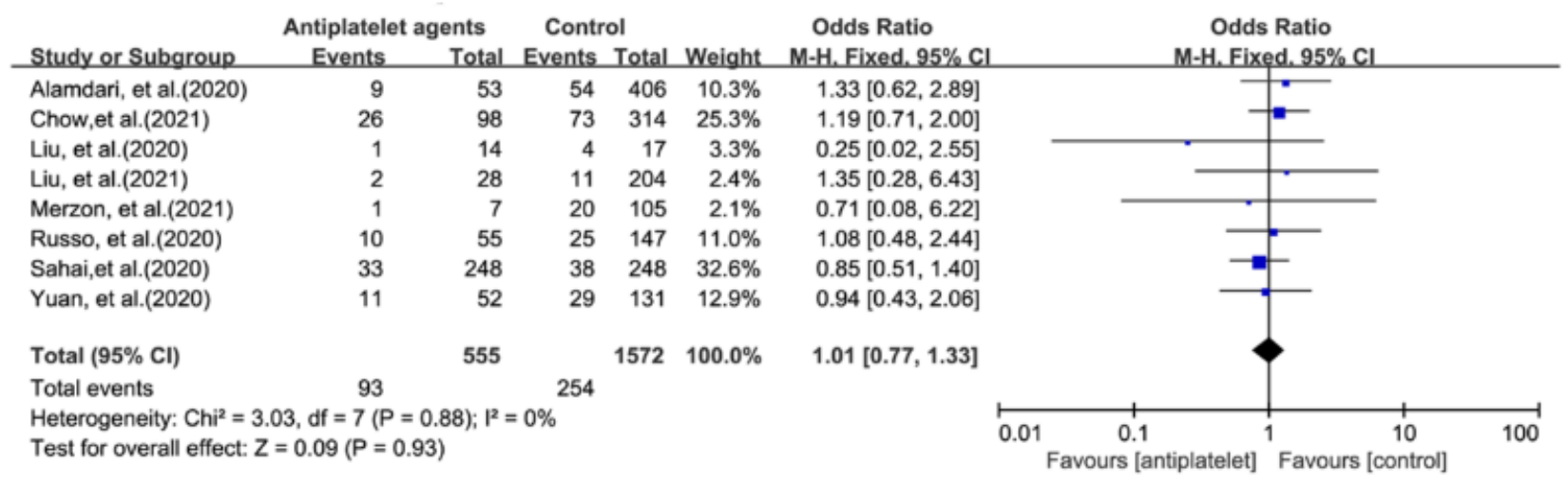

\section{Figure 2}

Forest plot examining the association between the use of antiplatelet agents and mortality outcomes in COVID-19 patients. 
A

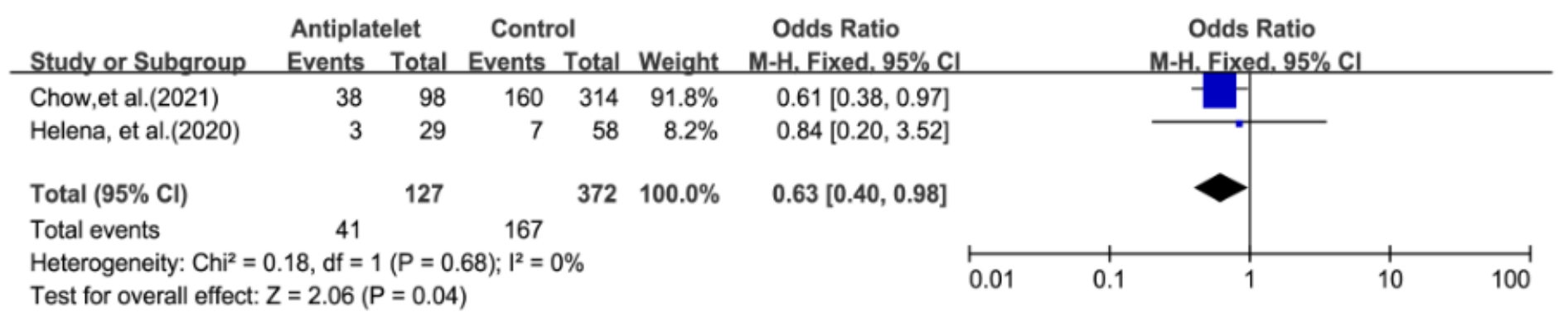

B

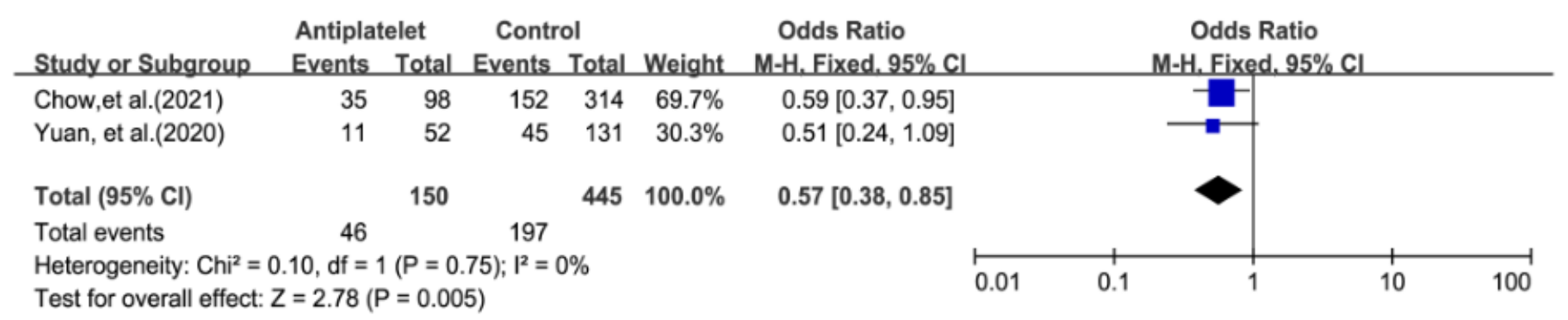

\section{Figure 3}

Forest plot examining the association between the use of antiplatelet agents and the risk of ICU admission (A) and mechanical ventilation (B) in COVID-19 patients. 
A

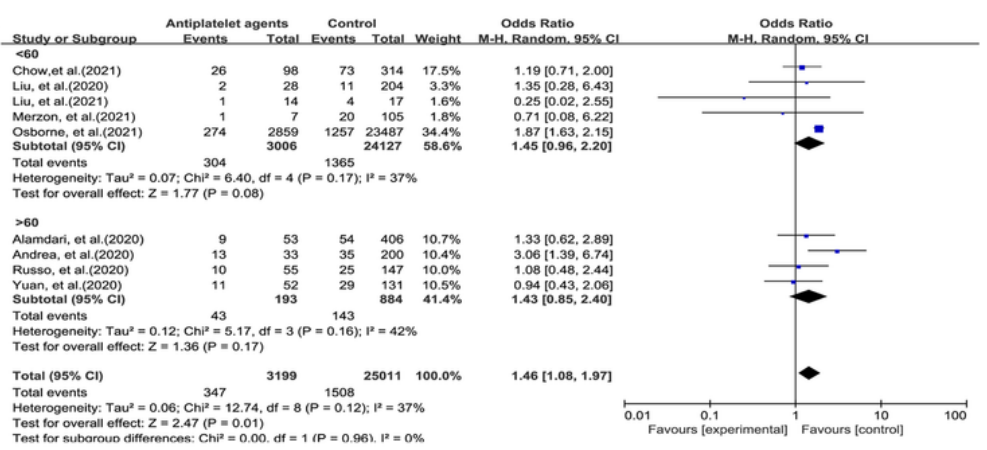

B

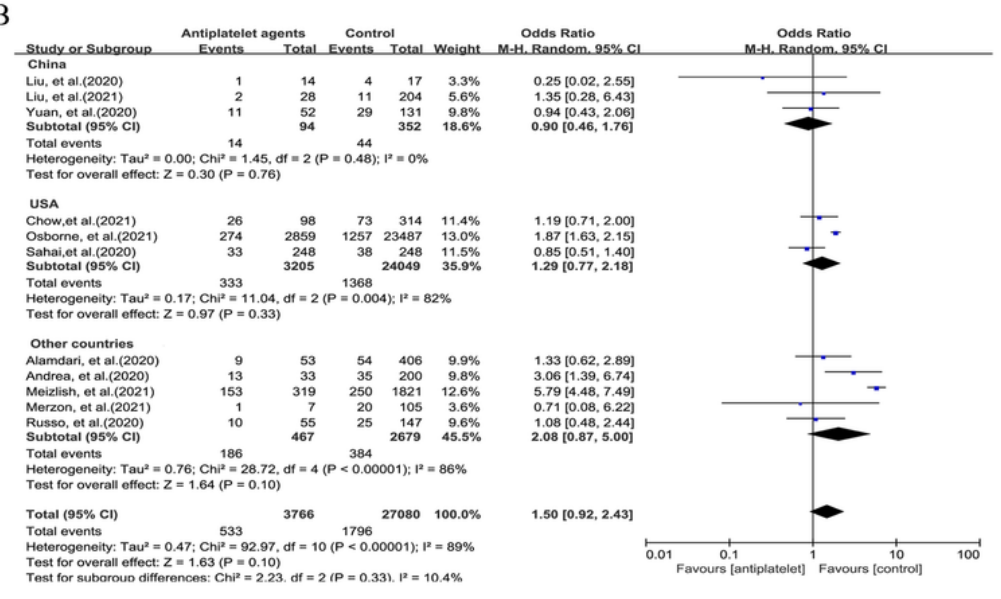

$\mathrm{C}$

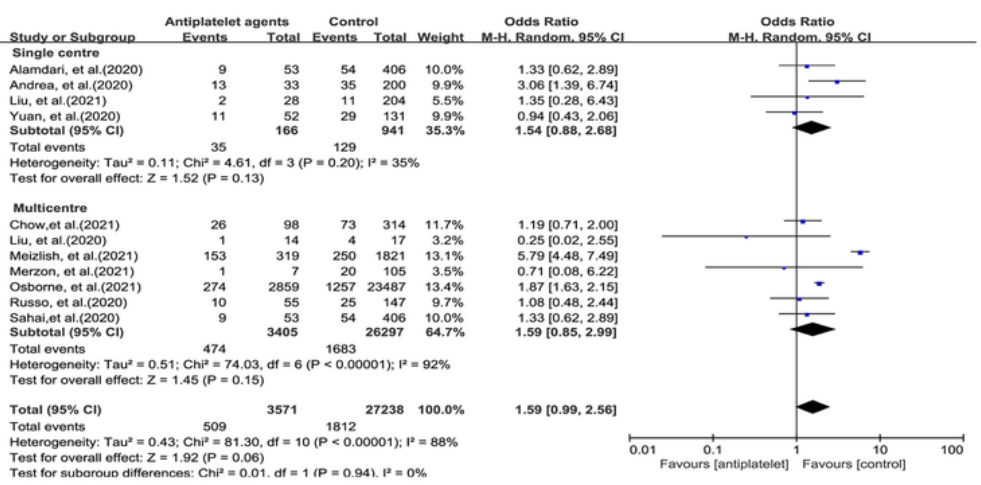

Figure 4

Forest plot examining the association between the use of antiplatelet agents and mortality outcomes in COVID-19 patients. (A) Subgroup analysis by factor of age. (B) Subgroup analysis by factor of region. (C) Subgroup analysis of by factor of type of study. 


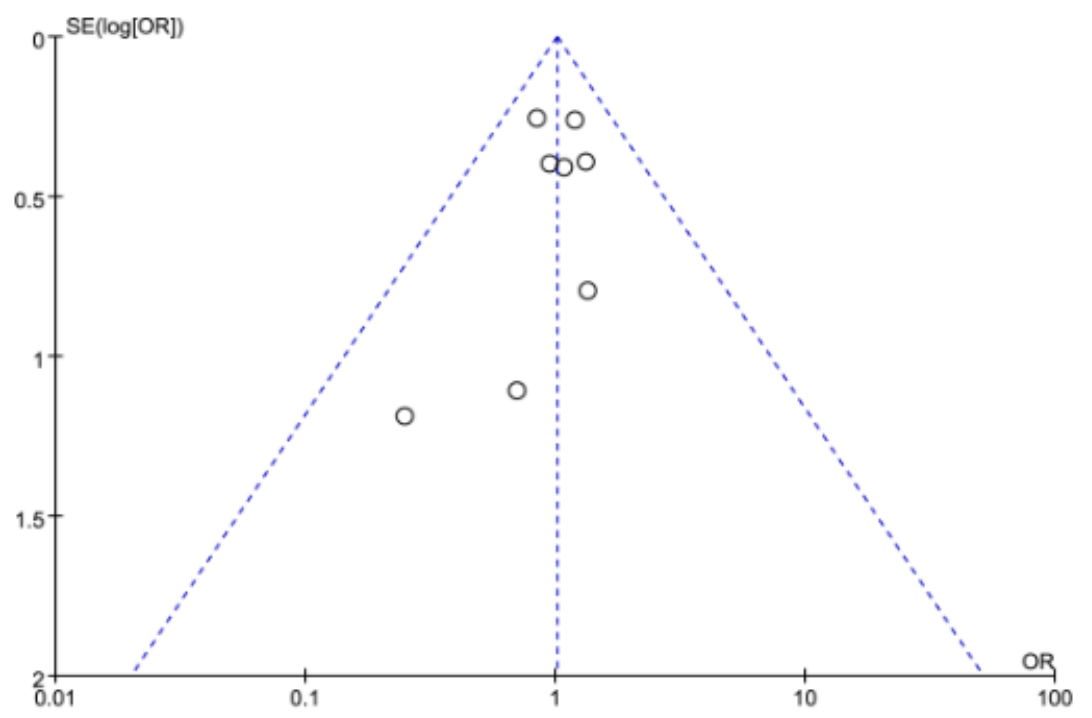

Figure 5

Funnel plots for assessment of publication bias.

\section{Supplementary Files}

This is a list of supplementary files associated with this preprint. Click to download.

- Supplementarymaterials.docx 